\title{
KEBERPIHAKAN PADA BAYANI ATAU IRFANI (SEBUAH PENDEKATAN BARU DALAM MEMAKNAI TEKS AL- QUR'AN)
}

\author{
${ }^{1}$ Supriadi \\ Sekolah Tinggi Agama Islam (STAI) Asy-Syukriyyah Tangerang \\ email: ucup.priadi@gmail.com
}

\begin{abstract}
Hermeneutics as part of the philosophy of language has become an instrument in interpreting a text including revelation texts in the Qur'an, in other words the study of hermeneutics is not only limited to the reality of searching for meaning in an existing text, but also explore meaning with three devices, namely the world of text, the world of the reader, and the world of the author. Hermeneutics works with two regional approaches, namely bayani and irfani, so there is hermeneutics that works in the bayani region called interpretation and hermeneutics that works in the irfani region called ta'wil which is implemented in Sufism. The ability of the Sufis to perform the Qur'an It is based on the assumption that the Qur'an does not have a single meaning, so it is still open to achieving the deepest meaning, so the Sufis try to dig it up by assuming the Qur'anic text as a sign or symbol. Excavation of this meaning there is only one way, namely the irfani method in order to find the meaning desired by the author, which is believed to be the possibility of intrinsic meaning.
\end{abstract}

Keyword: Bayani, Irfani; Al-Quran

\begin{abstract}
Abstrak: Hermeneutika sebagai bagian dari filsafat bahasa telah menjadi instrument dalam menafsirkan sebuah teks termasuk di dalamnya teks-teks wahyu dalam al-Qur'an, dengan kata lain yang menjadi kajian dalam hermeneutika bukan hanya terbatas pada kenyataan untuk mencari makna pada suatu teks yang ada, tetapi juga menggali makna dengan tiga perangkat yaitu dunia teks, dunia si pembaca, dan dunia si pengarang. Hermeneutika bekerja dengan dua pendekatan wilayah yaitu bayani dan irfani, sehingga ada hermeneutika yang bekerja pada wilayah bayani yang disebut tafsir dan hermeneutika yang bekerja pada wilayah irfani yang disebut ta'wil yang terimplementasi pada tasawuf. Kemampuan para sufi dalam melakukan penta'wilan al-Qur'an didasarkan pada asumsi bahwa alQur'an tidak memiliki makna tunggal, maka masih terbuka untuk mencapai makna yang terdalam, sehingga para sufi berusaha menggalinya dengan menganggap teks al-Qur'an sebagai isyarat atau simbol. Penggalian makna ini hanya ada satu jalan yaitu metode irfani dalam rangka mencari makna yang diinginkan si pengarang, yang diyakini kemungkinan itulah makna yang hakiki.
\end{abstract}

Kata kunci: Bayani, Irfani; Al-Quran 
ISTIGHNA, Vol. 2, No 2, Juli 2019 P-ISSN 1979-2824

Homepage: http://e-journal.stit-islamic-village.ac.id/index.php/istighna

Supriadi

Keberpihakan Pada Bayani Atau Irfani

(Sebuah Pendekatan Baru dalam Memaknai Teks Al-Qur'an)

\section{A. PENDAHULUAN}

Al-Qur'an dianggap sebagai fenomena yang penuh dengan sejarah keagamaan manusia, bahkan oleh pembacanya al-Qur'an dianggap berada di atas wilayah keduniaan sebagai firman Tuhan yang abadi dan tak tergantikan karena adanya jaminan Allah SWT. ${ }^{1}$

Dalam perkembangannya para mufassir berusaha memahami dan mengartikulasikan nilai-nilai qur'ani dan makna pesan Ilahi dalam kehidupan. Inilah yang menyebabkan timbulnya berbagai macam kecenderungan dalam memahami al-Qur'an, yaitu penafsiran dengan bantuan hadits dan perkataan para sahabat, penafsiran dogmatis, penafsiran mistik (ta'wil), penafsiran sektarian, dan penafsiran modern. ${ }^{2}$

Pendekatan tafsir yang cenderung positivistis sebagai satu-satunya pendekatan, bukan saja mendangkalkan makna yang digali al-Qur'an, tetapi juga kita akan terjebak dalam pola berfikir yang selama berabad-abad dibangun oleh filsafat barat seperti materialism, empirisme, dan positivism sebagai pijakan untuk melihat dunia.

Tafsir sebagai sebuah produksi dalam memaknai wahyu, jika dibiarkan menjadi satu-satunya cara memaknai al-Qur'an, maka ia akan menetapkan dirinya sebagai satu-satunya cara tersebut dan menafikan cara penggalian makna yang lain dengan epistemology yang berbeda. Salah satu jala membuka ini adalah kesediaan Ulumul Qur'an untuk memasukan dan mengkaji disiplin ilmu ta'wil, metode yang dipakai oleh para sufi yaitu dengan mengadopsi beberapa konsep yang ada dalam khazanah Islam dan barat, sehingga tidak ada lagi kesenjangan antara tafsir dan ta'wil.

Mengingat bahwa kedua sisi penafsiran dengan metode bayani dan irfani atau dalam istilah asing metode eksoterik dan esoteris memiliki urgensitas yang sama dalam kajian Islam. Dalam kasus tertentu tafsir eksoterik (bayani) tidak memadani untuk menjelaskan kandungan al-Qur'an. ${ }^{3}$ Menurut Quraish ${ }^{4}$ Shihab, tidak jarang menimbulkan masalah dalam pemikiran ketika diharapkan dengan kenyataan sosial dan hakikat ilmiahnya. Oleh karena itu elaborasi tentang penafsiran esoterik (irfani) dirasakan sangat penting. Dan dalam tulisan ini penulis memakai kata istilah eksoterik dengan bayani (tafsir), dan esoteris dengan irfani (ta'wil).

${ }^{1}$ Lihat Qs. Al-Hijr [15] : 9

${ }^{2}$ M.Husein Az-Zahabi, Tafsir wal Mufassirun, (Mesir: Darl Kutb Juz.2) h. 357

${ }^{3}$ Di antara ayat yang tidak dapat dipahami dengan pendekatan eksoterik (makna literal) adalah firman Allah swt, "Bukan kamu yang melempar ketika melempar, tetapi Allah-lah yang melempar.” (Q.S. Al-Anfāil/8:17). Makna sejati ayat itu, menurut Al-Gazālī, adalah samar, karena Allah menegaskan pelemparan sekaligus menyangkalnya. Pada titik inilah dibutuhkan pemaknaan secara esoterik. Lihat Abū Hāmid Al-Gazālī, Ihyā' 'Ulūm ad-Dīn, Bairut: Dār đadir, t.th., Jilid 1, hlm. 263; Nicholas Heer, "Tafsir Esoterik Al-Qur'an Abū Hāmid Al-Gazālī”, dalam Seyyed Hossen Nasr, et al., (Ed.), Warisan Sufi, terj. Gafna Raizha Wahyudi dari The Heritage of Sufism, Yogyakarta: Pustaka Sufi, h. 294-295

${ }^{4}$ Lihat dalam Membumikan al-Qur'an ; Fungsi dan Peran Wahyu dalam Kehidupan masyarakat, Bandung, Mizan, 2001 , h. 90 


\section{B. METODE KAJIAN}

Metode Kajian yang digunakan adalah kualitatif, metode penyajian datanya adalah deskriptif analisis, serta dirancang dengan pendekatan kepustakaan yang menelusuri beberapa literatur yang berkaitan dengan pembahasan tentang keberpihakan pada bayani atau irfani (sebuah pendekatan baru dalam memaknai teks Al-Qur'an).

\section{PEMBAHASAN}

\section{Kajian Hermeneutika}

Memberikan kejelasan tentang hakekat hermeneutika tentu saja jauh dari harapan untuk memperkenalkan wajah yang sebenarnya. Mengingat bahwa hermeneutika dalam arti sebuah pendekatan dalam ilmu filsafat, sesungguhnya merupakan disiplin ilmu yang sudah mengakar jauh ke dalam wacana kefilsafatan bahasa dan berkaitan dengan piranti-piranti lain, seperti semiologi dan strukuralisme. Oleh karena itu, tanpa mereduksi hakekatnya yang utuh, tulisan ini sedikitnya hanya mengangkat semangat hermeneutika sebagai pisau untuk membedah pesan-pesan al-Qur'an.

Hermeneutika bukan hanya mengubah pola dasar penafsiran tetapi juga telah mengubah pola dasar spiritualitas, sehingga dampaknya adalah terjadinya perubahan persepsi tentang agama, bahkan telah merubah pola kritik seni.

Hermeneutika diambil dari kata hermeneuen (Yunani) artinya "menafsirkan" atau hermenuia artinya "tafsiran". Hermeus dalam mitologi Yunani adalah anak dewa zeus yang diutus untuk menyampaikan pesan para dewa kepada manusia, sebab dia merupakan simbol perjalanan dan dilambangkan dengan planet mercury. Hermes dalam mitologi Yunani juga diyakini sebagai pembimbing ruh, membawa kasih sayang Tuhan dan semua kalangan. Dalam menyampaikan pesan khusus, hermeus terpaksa harus menafsirkan dulu. ${ }^{5}$ Oleh karena itu penafsiran ini pun berusaha menjelaskan pada teks mulai dari ciri-cirinya, baik objektif (gramatika, kata-kata, dan variasi historis) maupun subjektif (si pengarang).

Dari cerita di atas dapat disimpulkan bahwa hermeneutika adalah disiplin filsafat yang, mengungkapkan, dan menelusuri pesan dan pengertian dasar yang mengejawantah dari teks, wacana, isi, maksud dan makna terdalam (ultimate meaning).

Hermeneutika juga dijadikan mekanisme untuk mengungkap makna yang tertunda, guna mengembalikan komitmen wahyu Tuhan yang bersifa universal dan pluralis. Unsur inilah yang kemudian menjadi perenungan para filosof secara mendalam. Dengan demikian hermeneutika pada dasarnya merupakan metode atau cara untuk menafsirkan simbol yang berupa teks untuk dicari maknanya, yang mengisyaratkan adanya kemampuan untuk menafsirkan masa lampau yang tidak dialami kemudian dibawa ke masa sekarang.

Disisi lain hermeneutika juga dipandang tidak hanya memandang teks dan berusaha menyelami kandungan makna literalnya, tetapi lebih dari itu hermeneutika berusaha menggali makna dengan mempertimbangkan horizon-

${ }^{5}$ Lexion University Ensiklopedi (Washington DC, vol. 10 
horison yang melingkupi teks tersebut. Horizon yang dimaksud adalah horizon teks, horizon pengarang, dan horizon si pembaca. ${ }^{6}$

Dari ketiga horizon tersebut, diharapkan suatu upaya penafsiran menjadi kegiatan rekonstruksi dan reproduksi makna teks. Disamping melacak bagaimana suatu teks itu dimunculkan oleh pengarangnya dan muatan apa yang masuk dan yang ingin dimaksudkan oleh si pengarang ke dalam teks yang dibuatnya, juga berusaha melahirkan kembali makna tersebut sesuai dengan situasi dan kondisi saat teks tersebut dibaca dan dipahami. Dengan kata lain, sebagai sebuah metode penafsiran hermeneutika memperhatikan tiga horizon tersebut sebagai komponen pokok dalam upaya penafsiran terhadap teks, konteks, dan kontekstualisasi.

\section{Kajian Tafsir Pendekatan Metode Bayani Dan Irfani}

\section{a. Pengertian, asal usul kelebihan dan kekurangan Metode Bayani}

Kata bayani berasal dari bahasa arab yaitu al-bayani yang secara harfiah bermakna sesuatu yang jauh atau sesuatu yang terbuka. Namun secara terminologi, ulama berbeda pendapat dalam mendefenisikan al-bayani.

Para ahli balaghah mendefinisikan al-bayani sebagai ilmu yang dapat mengetahui satu makna dengan beberapa cara atau metode seperti tasbih (penyerupaan), majaz dan kinayah. Sedangkan ulama teologi berpandangan bahwa bayani adalah dalil yang dapat menjelaskan hukum. Sebagian yang lain mengatakan bahwa al-bayani adalah ilmu baru yang dapat mengeluarkan sesuatu dari kondisi samar-samar (subhat) kepada kondisi jelas (muhkam).

Namun dalam epistimologi Islam bayani adalah metode pemikiran khas Arab yang menekankan pada otoritas teks (nash) secara langsung atau tidak langsung dan dijustifikasi oleh akal kebahasaan yang digalih lewat inferensi (istidlal). ${ }^{7}$

Secara langsung metode bayani adalah mamahami teks dalam hal ini teks wahyu sebagai pengetahuan, dan langsung mengaplikasikan tanpa perlu pemikiran. Namun secara tidak langsung bayani berarti memahami teks sebagai pengetahuan mental sehingga perlu tafsir dan penalaran. Meski demikian, hal ini tidak berarti akal atau rasio bisa bebas menentukan makna suatu teks, tetapi tetap harus bersandar pada teks. Sehingga dalam bayani, rasio dianggap tidak mampu memberikan pengetahuan kecuali disandarkan pada teks. Dalam perspektif keagamaan, sasaran bidik metode bayani adalah aspek eksoterik (dzohir).

Pada awalnya metode bayani dimulai dari masa Rasulullah SAW dimana beliau menjelaskan ayat-ayat yang sulit dipahami oleh sahabat. Kemudian para sahabat menfsirkan Al-Quran dari ketetapan yang telah diberikan Rasulullah SAW melalui teks. Selanjutnya tabi'in mengumpulkan teks-teks dari Rasulullah SAW dan sahabat, kemudian mereka menambahkan penafsirannya dengan kemampuan nalar dan ijtihadnya dengan teks sebagai pedoman utama. Pada generasi setelah tabi'in yang melakukan penafsiran

\footnotetext{
${ }^{6}$ E. Sumaryono, Hermeneutika ; Sebuah metode filsafat (Yogyakarta: Kanisius, 1999) h. 12
}

${ }^{7}$ A. Bachrun Rifai dkk, Filsafat Thasawuf, (Bandung: Pustaka Setia, 2010), h. 90 
sebagaimana pendahuluannya sampai berkelanjutan kepada generasi yang lain. ${ }^{8}$

Tentang Epistimologi bayani, pada dasarnya telah digunakan oleh para fuqaha, mutakallimun, dan usulliyun dimana mereka menggunakan bayani untuk (a). Memahami atau menganalisis teks guna menemukan atau mendapatkan makna yang dikandung atau dikehendaki dalam lafaz, dengan kata lain pendekatan ini dipergunakan untuk mengeluarkan makna zahir dari lafaz yang zahir pula. (b) Istinbat (pengkajian) hukum-hukum dari al-nusus al-diniyyah (al-Quran dan Hadits). ${ }^{9}$

Menurut hemat penulis dalam bahasa filsafat metode bayani dapat diartikan sebagai model metodologi berpikir yang didasarkan atas teks. Dalam hal ini teks sucilah yang memiliki otoritas penuh menentukan arah kebenaran. Fungsi akal hanya sebagai pengawal makna yang terkandung di dalamnya yang dapat diketahui melalui pencermatan hubungan antara makna dan lafaz. Metode bayani (observasi) ditujukan untuk melakukan pengkajian terhadap objek-objek yang bersifat indrawi dan menghasilkan pengetahuan sains.

Dominasi terhadap metode bayani (tafsir dzohir) ini menimbulkan stagnasi dalam kehidupan beragama, karena ketidakmampuannya merespon perkembangan zaman. Hal ini dikarenakan epistimologi bayani selalu menempatkan akal menjadi sumber sekunder sehingga peran akal menjadi terpasung dibawah bayang-bayang teks dan tidak menempatkannya secara sejajar, saling mengisi dan melengkapi dengan teks. ${ }^{10}$ Sementara kelebihan metode bayani terletak pada kebenaran teks (Al-Quran dan Hadits) sebagai sumber utama hukum islam yang bersifat universal sehingga menjadi pedoman dan patokan.

\section{b. Pengertian, asal usul kelebihan dan kekurangan Metode Irfani}

Kata Irfani berasal dari bahasa arab yang memiliki makna sesuatu yang berurutan yang sambung satu sama lain dan bermakna diam dan tenang. Secara harfiyah al-irfan adalah mengetahui sesuatu dengan berfikir dan mengkaji secara mendalam. Secara terminologi, irfani adalah pengungkapan atas pengetahuan yang diperoleh lewat penyinaran hakikat oleh Tuhan kepada hambanya (al-kasyf) setelah melalui tahapan riyadhoh (latihan).

Para pakar berbeda pendapat tentang asal mula sumber irfani. Sebagian golongan menganggap bahwa irfani berasal dari persia dan majusi seperti yang disampaikn oleh Dozy dan Thoulk. Alasannya bahwa sejumlah orangorang besar sufi berasal dari Khurasan dan kelompok Majusi. Sebagian yang lain mengatakan bahwa irfani bersumber dari Kristen sebagaimana yang diuangkapkan oleh Von Kramer, Ignaz Goldziher, Nicholshon, Sebagian besar yang lain berpendapat bahwa irfani bersumber dari India. ${ }^{11}$ Namun

\footnotetext{
${ }^{8}$ Ali Saifullah, Antara Filsafat dan Pendidikan, (Surabaya: Usaha Nasional, 1989), h. 45

${ }^{9}$ Ibid., h. 91

${ }^{10}$ Ibid., h. 47

11 Mulyadi Kartanegara, Menembus Batas Waktu Panorama Filsafat Islam, (Bandung: Mizan Pustaka, 2005), h. 123
} 
demikian bahwa irfani tidak berasal dari luar Islam sebab kehidupan Rasulullah SAW. Para sahabat dan tabi'in menunjukkan bahwa mereka dalam suatu waktu akan menggunakan irfani, meskipun penanamannya belum ada.

Pendekatan yang dilakukan irfani adalah memandang pengetahuan diskursif (al-hikmah al-batiniyyah) harus dipadu dengan pengetahuan intuitif (al-hikmah al-zawqiyah). Dengan pemaduan tersebut pengetahuan yang diperoleh menjadi pengetahuan yang mencerahkan, bahkan akan mencapai al-hikmah al-haqiqiyyah. Pengalaman batin Rasulullah SAW dalam menerima wahyu merupakan contoh dari pengetahuan irfani. $^{12}$

Dalam filsafat, irfani lebih dikenal dengan istilah intuisi. Dengan intuisi, manusia memperolah pengetahuan secara tiba-tiba tanpa melalui proses penalaran tertentu. Ciri khas intuisi antara lain: zauqi (rasa) yaitu melalui pengalaman langsung, ilmu huduri yaitu kehadiran objek dalam diri subjek, dan eksistensial yaitu tanpa melalui kategeorisasi akan tetapi mengenalnya secara intim. Henry Bregson menganggap intuisi merupakan hasil dari evolusi pemikiran yang tertinggi tetapi bersifat personal. ${ }^{13}$ Implikasi dari pengetahuan irfani dalam konteks pemikiran keislaman, adalah menghampiri agama-agama pada tataran substantif dan esensi spritualnya, dan mengembangkannya dengan penuh kesadaran akan adanya pengalaman keagamaan orang lain yang berbeda aksidensi dan ekspresinya, namun memiliki substansi dan esensi yang kurang lebih sama.

Dengan demikian dapat ditarik kesimpulan bahwa metode irfani (intuitif) digunakan untuk memahami secara langsung realitas metafisis yang bersifat huduri dalam jiwa manusia dan menghasilkan pengetahuan mistik.

Keunggulan metode irfani adalah bahwa segala pengetahuan yang bersumber dari intuisi-intuisi musyahadah dan musyakafah, lebih dekat dengan kebenarannya dari pada ilmu-ilmu yang digali dari argumentasiargumentasi rasional dan akal. Bahkan kalangan sufi menyatakan bahwa indra-indra manusia dan fakultas akalnya hanya menyentuh wilayah lahiriyyah alam dan manifestasi-manifestasinya. Namun manusia dapat berhubungan secara langsung (immediate) yang bersifat intuitif dengan hakikat tunggal alam (Allah) melalui dimensi-dimensi batiniyyah sendiri dan hal ini akan sangat berpengaruh ketika manusia telah suci, lepas, dan jauh dari segala bentuk ikatan-ikatan dan ketergantungan-ketergantungan lahiriyyah. Namun keterbatasan metode irfani adalah bahwa ia hanya dapat dinikmati oleh segelintir manusia yang mampu sampai pada taraf pensucian diri yang tinggi. Disamping itu irfani sangat subjektif menilai sesuai karena ia berdasar pada pengalaman individu manusia. ${ }^{14}$

12 Mulyadhi Kartanegara, Menyibak Tirai Kejahilan Pengantar Epistimologi Islam (Bandung: Mizan Pustaka, 2003), h. 56

${ }^{13}$ Ibid, h. 58

${ }^{14}$ Ibid, h. 130 
ISTIGHNA, Vol. 2, No 2, Juli 2019 P-ISSN 1979-2824

Homepage: http://e-journal.stit-islamic-village.ac.id/index.php/istighna

Supriadi

Keberpihakan Pada Bayani Atau Irfani

(Sebuah Pendekatan Baru dalam Memaknai Teks Al-Qur' an)

\section{Latar Belakang Hermeneutika Irfani}

Setiap bahasa tidak terlepas dari dua dimensi yaitu dimensi eksternal (zahiri/eksoteris) dan dimensi internal (bathin/irfani). Dimensi ekternal adalah situasi psikologis dan intensi atau kehendak fakir, sedangkan dimensi internal adalah tindakan penafsiran dan mengekspresikan kehendak bathin dalam bentuk wujud lahir yaitu kata-kata yang diwujudkan kepada orang lain.

Pandangan irfani sebagai fenomena keagamaan yang dalam tradisi Islam mengambil bentuk tasawuf didasarkan pada keyakinan bahwa segala sesuatu yang, literal, ekternal, eksoterik, memiliki hubungan korespondensif dengan yang tersembunyi, spiritual, internal, dan essoterik (bathin).

Hubungan korespondensif ini secara ilustratif dapat diperjelas dengan analogi hubungan antara keanekaragaman warna yang nampak dengan cahaya yang tidak terlihat. Cahaya dalam dirinya sendiri adalah realitas yang tidak Nampak, hanya setelah bercampur dengan kegelapan cahaya dapat tampil dalam keanekaragaman bentuk, dan objek kasat mata. Tidak ada satupun yang terlihat tanpa keberadaan cahaya, sekalipun dalam dirinya ia tidak terlihat. ${ }^{15}$

Bila digabungkan dua istilah di atas, maka akan ditemukan beberapa pemikiran baru yaitu hermeneutika yang bersifat bayani dan irfani. Dalam Islam hermeneutika bayani disebut tafsir sebuah metode memahami al-Qur'an secara leterlek, zahir dan tidak keluar dari makna teks, sedangkan hermeneutika irfani dalam Islam disebut ta'wil yaitu pengungkapan atau suatu realitas atau teks dengan intuisi, bathin, dan terkadang keluar dari teks.

Hermenutika bayani (tafsir) dalam proses pemaknaan terhadap realitas dilakukan dengan cara dialog inter subjektif dengan maksud tercapainya kesepakatan. Retorika dalam hal ini memainkan peranan penting yakni untuk meyakinkan banyak orang akan "kebenaran" suatu realitas, verifikasi terhadap suatu kesepakatan dicari dalam kesinambungan dialog dan tercapainya kesepakatan baru, jika kesepakatan sebelumnya tidak lagi di anggap memadai, demikian seterusnya. ${ }^{16}$ Adapun hermeneutika irfani (ta'wil) kedalam kesadaran justru menjadi kriteria bagi pencapaian kebenaran dan dengan pemahaman pada perspektif metaforis - irfani yang lebih berorientasi internal dan vertical. Sebab, perspektif empiris yang terjadi pada hermeneutika bayani lebih pada pengembangbiakan cabang-cabang pengetahuan atau hasil pengalaman atas realitas dan bukan pada sumber sebagaimana obsesi perspektif metafisis.

Hermeneutika irfani (ta'wil) menganggap bahwa alam merupakan manifestasi Tuhan sebagai sumber eksistensi, maka pemaknaan atau atau interpretasi terhadap realitas dilakukan dengan mengembalikan segala sesuatu ke asal usul Ilahiyahnya. Cara seperti ini bisa dirujuk sebagai ta'wil atau hermeneutika irfani yang secara etimologis berarti membawa segala sesuatu kembali ke permukaan.

${ }^{15}$ William Chittik, Imaginal World ; Ibnu 'Arabi and the problem of religion diversity (New York State University, 1995) h. 16 1996) h. 41

16 Bambang Sugiharto, Post Modernisme, Tantangan bagi filsafat (Yogyakarta: kanisius, 
Dahulu, sebagian ulama merasa puas dengan menyatakan bahwa "Wallahu a 'lam bi muradihi" (Allah yang mengetahui maksud-Nya). Tetapi, ini tentunya tidak memuaskan banyak pihak, apalagi dewasa ini. Karena itu, sedikit demi sedikit sikap seperti itu berubah dan para mufasir akhirnya beralih pandangan dengan jalan menggunakan $t a$ 'wil. Memang, literalisme (penafsiran) seringkali mempersempit makna, berbeda dengan penta'wilan yang memperluas makna sekaligus tidak menyimpang darinya. Di sinilah ta'wil dibutuhkan dalam memahami al-Qur'an.

الرجوع إلي " yang berarti "الاول" Tal sendiri secara bahasa berasal dari kata " للأصل " (kembali kepada asal). Bila dikatakan: "آل إليه أولا ومآلا" الآل kepadanya. Dan apabila dikatakan: "أول الكلام تأويلا" artinya: memikirkan, memperkirakan dan menafsirkannya. Atau seperti diungkapkan Al Shabuni dalam Al Thibyan Fi 'Ulum Al Qur'an, ta'wil seperti makna leksikalnya (masdar), " mempunyai makna " دبّره وقدّره و فيّره " "merenungkan, mengirangirakan, dan mentafsirkan". ${ }^{17}$ Secara istilah, menurut golongan salaf, ta'wil mempunyai dua arti, yaitu:

هو تفسيرالكلام و بيان معناه, سواءفق ظاهره او خالفه, فيكون التأويل و التفسير علي هذامترادفين

"Penafsiran kalam dan penjelasan maknanya. Dalam hal ini arti ta'wil sama dengan tafsir."

Pemaknaan yang kedua kaum salaf memaknai ta 'wil sebagai berikut:

هو نفس المراد بالكلام , فانّ الكلام طلبا كان تاويله نفس الفعل المطلوب ، وان كان خبرا, كان تاويله

نفس الشيءالمخبر به.

"Ta'wil dalam makna ini berarti menjelaskan kalam dengan sesuatu yang sesuai dengan yang dikehendaki / dimaksud kalam. Misalnya apabila kalam berbentuk perintah, maka takwilnya berupa perbuatan yang memenuhi perintah tersebut."

Adapun menurut muta'akhkhirun (golongan ulama kontemporer) ${ }^{18}$, mendefinisikan $t a$ 'wil sebagai berikut:

$$
\text { هو صرف اللفظ عن المعني الراجح الي المعني المرجوح لدليل يقترن به. }
$$

"Sebagai memalingkan/mengganti makna lafadz yang kuat (rajih) kepada makna yang lemah (marjuh) karena adanya dalil yang menyertainya"

\section{Hermeneutika Irfani Dan Ontologi Al-Qur'an}

Tidak seperti tafsir, ta'wil sebagai hermeneutika irfani bukan sekedar bagaimana "memaknai" al-Qur' an akan tetapi lebih dari itu, $t a$ 'wil juga meliputi masalah bagaimana "memandang dan memposisikan" al-Qur'an.

Dalam ta'wil, masalah ontologi al-Qur'an mendapatkan tempat yang signifikan. Hal ini didasarkan pada asumsi bahwa ta'wil tidak hanya memuat metode untuk menggali makna, akan tetapi lebih dari itu ta'wil adalah sebuah

${ }^{17}$ Ali Al Shabuni, Al Itqaan fi Ulumil Qur'an. H. 66. lihat juga dalam Al Dzahabi, Al Tafsir Wa al Mufassiruun... h. 14

${ }^{18}$ Yang dimaksud adalah mereka yang dari golongan ahli fiqih, ahli kalam, dan tasawuf 
penjelasan mengenai transpormasi makna (ide Tuhan) yang justru didalamnya juga melibatkan manusia sebagai subjek al-Qur'an dan alam. ${ }^{19}$ Jika dalam tafsir langsung memposisikan al-Qur'an sebagai sebuah mushaf (korpus) yang utuh yang siap untuk digali maknanya. Sedangkan ta'wil lebih dari sekedar mushaf atau korpus dan entitas bahasa. Karenanya pembahasan ta'wil pada titik ini untuk selanjutnya diistilahkan sebagai ontologi al-Qur'an.

\section{Sistem Kerja Hermeneutika Irfani}

Ilmu pengetahuan modern membagi otak manusia ke dalam dua bagian yaitu otak kiri dan otak kanan. Otak kiri bersifat linier dan logis yang mampu mengembangkan kemampuan berbahasa, menghitung, dan menganalisa. Sedangkan otak kanan bersifat intuitif irasional. ${ }^{20}$ Otak kanan memiliki gaya yang holistic dalam memandang informasi gaya holistic ini berhubungan dengan kreativitas, imaginer, visual, perasaan, simbol-simbol dan sintesa.

Orientasi masyarakat modern pada umumnya bersikap rasional dan logis, yang dapat dibuktikan diberbagai wilayah kehidupan. Para insinyur, dokter, hakim, dan lainnya dianggap benar jika mereka mampu mengambil keputusan secara logis dan rasional. Namun akan menjadi negative jika cara berfikir dan rasional dengan otak kiri ini menjadi satu-satunya cara berfikir dan mensubbordinasikan cara berfikir yang lain.

Kekhawatiran ini memang terbukti, cara berfiir dengan otak kanan membuat manusia lupa akan potensi yang lain. Sesungguhnya manusia memiliki sifat intuitif dan rasional yang dijalankan oleh otak kanan. Otak kanan lah yang justru memiliki kreatifitas imaginer, visual, perasaan, symbol dan sintesa.

Jika kedua otak ini dengan fungsinya dengan fungsinya kita hubungkan dengan masalah pemaknaan al-Qur'an, maka dapat disimpulkan bahwa tafsir sebagai hermeneutika bayani bekerja dengan memanfaatkan fungsi otak kiri, sedangkan $t a$ 'wil sebagai hermeneutika irfani menggunakan otak kanan sebagai perangkatnya.

Proses hermeneutika irfani sebagai sebuah transpormasi transcendental terjadi jika manusia sebagai kutub subjektif berada dalam kondisi spiritual yang prima. Karena proses transpormasi ini bukanlah proses verstsehen, yaitu bukan akal yang menggapai pengertian, melainkan Tuhan itu sendiri yang langsung memberikan pemahaman yang hanya bisa diraih dengan penyerahan diri sepenuhnya sebagaimana yang ada pada karakter sufi. Karenanya Jalaludin alRumi memperlakukan al-Qur'an sebagai mempelai wanita ('arus);

"Al-Qur'an itu seperti mempelai wanita, meskipun kamu menarik selubung dari wajahnya, dia tidak akan menunjukkan dirinya padamu ketika kamu mengkaji al-Qur'an tetapi tidak merasakan kesenangan atau pengungkapan itu karena tindakan kamu menarik selubung itu yang mengakibatkan dirimu di tolak. Al-Qur'an menipumu dan menunjukkan dirinya sebagai siburuk tua. Dia berkata; aku bukanlah mempelai cantik itu, ia dapat menunjukkan apapun dalam bentuk yang diinginkannya, tetapi jika kamu menghentikan menarik selubung

\footnotetext{
${ }^{19}$ Lihat Qs. Pusshilat : 53

${ }^{20}$ Gini Graham, Mind Power, (Jakarta: Grasindo, tth,) h. 2
} 
mukanya dan menikmatinya dengan baik, jika kamu mengairi ladangnya, melayaninya dari jauh dan mengusahakan yang disukainya, maka ia akan menunjukkan wajahnya padamu tanpa kamu menyingkap selubungnya", ${ }^{21}$

Berijtihad dalam melakukan $t a$ 'wil atas teks, tidak dibedakan teks dibidang fiqih dan hukum dengan teks di bidang lainnya, sebab ijtihad didasarkan atas gerak "nalar" untuk menembus kedalaman makna teks. Hal ini tidak berarti bahwa hermeneutika irfani atau ta'wil yang bersifat objektif terhadap teks wahyu sulit direalisir, sebab menolak objektifitas sebenarnya akan memapankan subjektifitas.

Objektifitas dalam merealisir suatu teks adalah melalui objektifitas kultural yang terikat dengan ruang dan waktu. Objektifitas ini dapat terwujud melalui muawwil yang "menenggelamkan diri" ke dalam teks dalam upaya menembus kedalaman maknanya. Akibatnya penemuan dari makna-makna baru, tidak berarti menggugurkan makna-makna yang telah ditemukan sebelumnya.

\section{Hermeneutika Irfani Dalam Tafsir Isyari (Tafsir Sufi)}

Dari berbagai corak yang disebut sebagai "kitab tafsir" ada beberapa corak yang sesungguhnya bisa disebut sebagai "kitab ta'wil" yang penulisannya menggunakan metode hermeneutika irfani. Diantaranya adalah tafsir sufi nazhari dan tafsir shufi isyari (bathini). Pada tafsir shufi, si penafsir terlebih dahulu memiliki konsep tasawuf yang mungkin saja berasal dari al-Qur'an, kemudian pemahaman tasawufnya mempengaruhi penafsirannya, sehingga disini tasawuf menjadi sebuah kecenderungan (ittijah) seperti juga seorang ahli bahasa memiliki kecenderungan kebahasaan (lughawi) ketika menafsirkan alQur'an.

Tafsir isyari (ta'wil) lebih merupakan sebuah sumber aktivitas penafsiran seperti juga ma'tsur (informatif) dan ra'yu. Penafsiran secara isyari berarti menggali makna al-Qur'an dengan menggunakan sumber intuisi yaitu mencari makna al-Qur'an dari sisi yang tidak terjangkau oleh akal dan informasi (atsar) pada tafsir isyari si penafsir tidak "memaksakan" konsep tasawuf ketika menafsirkan suatu ayat seperti yang terjadi pada tafsir shufi nazhari. ${ }^{22}$

Dengan pembedaan di atas, maka kita akan melihat ketidaksetaraan antara tafsir sufi isyari dan tafsir sufi nazhari. Jika yang pertama dikelompokkan pada tafsir ma'tsur dan ra'yu, maka yang kedua dikelompokkan dengan lughawi, ilmu falsafi, dll. Ketika berbicara tafsir isyari, maka harus membicarakn bagaimana isyari itu menjadi sebuah sumber untuk memahami sebuah teks.

Menanggapi tafsir isyari ini, imam al-Alusi memberikan prasyarat atau batasan tentang validitas sebuah penafsiran isyari. Diantara prasyarat itu tafsirnya tidak bertentangan dengan kaidah umum, tidak meninggalkan makna zahir dan tidak menganggap bahwa penafsirannya yang paling benar dan yang lain adalah salah. Tafsir bathini adalah jenis tafsir yang berkembang di dalam

${ }^{21}$ Sachiko murata, The Tao Of Islam, (Bandung: Mizan, 1997) h. 301

${ }^{22}$ Az-Zahabi , tafsir wal mufassirun,.. j.2 h.381 
lingkungan syiah Ismailiyyah. ${ }^{23}$ Beberapa peletak dasar aliran tafsir ini adalah Abdulah bin Maimu al-Qadah, yaitu salah satu pembantu Ja'far Muhammad AsShodiq, Muhammad bin Husein. Dikategorikan sebagai ta'wil karena bathini. Seperti tercermin dalam namanya, tafsir ini menggunakan metode pemaknaan al-Qur'an dengan mencari makna dibelakang lafadz zahirnya secara eksplisit. Az-Zahabi pernah menulis; "sesungguhnya kelompok bathini telah melakukan ta'wil atas al-Qur'an secara bab perbab untuk mencapai tujuan mereka". ${ }^{24}$

Pada perkembangannya selanjutnya bathini diklasifikasikan menjadi dua bagian yaitu kelompok mutaqaddimin dan mutaakhirin. Selain dari kelompok ismailiyah ada juga kelompok dari Zaidiyah yang juga merupakan sekte Syiah yang di sebut-sebut paling dekat dengan kaum sunni. Namun bathini dari Ismailiyah maupun bathini dari Zaidiyah, tidak akan dikembangkan terlalu luas dalam penulisan ini, mengingat tulisan ini hanya membahas tafsir isyari saja.

\section{Sekilas Beberapa Tafsir Isyari (Sufi)}

\section{a. Tafsir al-Qur'an al-Adzim (al-Tusturi)}

Penyusunnya adalah Abu Muhammad Sahal bin Abdullah bin Yunus bin Abdullah al-Tusturi. Dia lahir di Tustur di wilayah Ahwaz Iran tahun $200 \mathrm{H}$, dan meninggal di Bashra pada tahun 283/986. Semasa hidupnya dia tidak pernah menulis sebuah kitab secara formal, akan tetapi semua pemikirannya ditulis dan dikoleksikan oleh muridnya Muhammad bin Salim. ${ }^{25}$

Kitab ini di cetak dengan jilid yang kecil. Metode yang diterapkannya adalah tidak disajikan ayat perayat melainkan ayat-ayat yang terbatas yang terpisah-pisah. Dalam memberikan penjelasannya ia selalu memulainya dengan makna zahir sebelum bathinnya. Namun ketika ia mengungkapkan makna isyari, kadang ia tidak mengupasnya hingga jelas, bahkan ia kadang menggunakan kata asing (gharib).

Pengungkapan secara isyari yang terkadang ini dilakukan Tusturi karena beliau pernah berkata dalam muqoddimah kitabnya bahwa "tiap-tiap ayat dalm al-Qur'an mempunyai empat makna; zahir, bathin, had, dan mathla". Terangnya hati dengan pemahaman di atas apa yang dikehendaki ayat tersebut adalah pemahaman yang datang dari Allah.

Mahmud Basuni Faudah memandang bahwa Tusturi tidak membatasi diri pada makna-makna bathin saja, sekalipun makna secara bathin mendominasi dalam penafsirannya. Terkadang memaknainya secara zahir dan terkadang secara bathin. ${ }^{26}$

\section{b. Haqaiq At-Tafsir (Al-Sulami)}

Penyusunnya adalah Abu Abdurrahman Muhammad bin Husein bin Musa, lahir tahun $330 \mathrm{H}$ dan wafat $412 \mathrm{H} / 1021 \mathrm{M}^{27}$ beliau adalah seorang

${ }^{23}$ Ismailiyah adalah salah satu sekte dari syiah imamiyah. Ismailiyah dinisbahkan kepada imam yaitu Ismail bin Ja'far al-Shadiq.

${ }^{24}$ Az-Zahabi, h.

${ }^{25}$ Michael A. Salls, Early Islamic Mysticism, (New York: Paulist Press, 1996) h. 90

${ }^{26}$ Mahmud Basuni Faudah, Tafsir-Tafsir al-Qur'an, (Bandung: Pustaka, 1987) h.261

27 Ibid 
syeikh dan ulama sufi pada masanya. Selain itu beliau juga seorang ahli hadits. Pernah diriwayatkan bahwa beliau menuturkan hadits selama 40 tahun dengan mendiktekan dan membacakannya.

Kitab tafsir ini hanya satu jilid yang tebal yang dicetak oleh Maktabah al-Azhar. Tafsir ini memuat semua surat al-Qur'an namun tidak semua ayat disajikan. Tidak seperti al-Tusturi, al-Sulami lebih memberikan perhatian kepada makna-makna isyari dan mengabaikan makna zahir. Sebagian besar tafsirnya terdiri dari pendapat-pendapat para ahli hakekat yang dia susun berdasarkan susunan surat al-Qur'an. Sumber yang dia gunakan adalah berupa riwayat yang dinishbatkan kepada Ja'far Shadiq, Ibnu Athaillah asSakandari, Junaidi al-Baghdadi, Fudhail Ibn Iyadh, Sahl Ibnu Abdullah alTusturi dan lain-lain. ${ }^{28}$

Banyak para ulama mengecam tafsir ini, diantaranya adalh Imam aslSuyuthi yang menggolongkan beliau sebagai mufassir mubtadi (mengadangada) dengan alasan karena tafsirnya tidak terpuji. ${ }^{29}$

\section{c. Araais al-Bayan Fii Haqaaiq al-Qur'an (Asy-Syairazi)}

Penulisnya adalah Abu Muhammad Asy-Syirazi (w. 666 H) dari muqaddimah kitab kita bisa mengetahui bahwa penulisnya mengakui adanya zahir selain makna bathin, namun demikian Az-Zahabi menilai bahwa kitab ini murni merupakan tafsir isyari yang hampir sama sekali tidak memuat tafsir-tafsir yang bersifat zahir.

\section{d. Al-Ta'wilat al-Najmiyah (As-Sam'ani)}

Kitab ini sempat diselesaikan oleh penulisnya, karena Najmuddin Dayah keburu meninggal pada tahun $654 \mathrm{H}$. selanjutya kitab ini dilanjutkan oleh 'Alaa al-Daulah al-Sam'ani $(w .736 \mathrm{H})^{30}$ sehingga kitab ini menjadi karya kolaborasi antara imam sufi besar. Penulisan kitab ini ternyata terulang pada masa selanjutnya yaitu ketika Muhammad Abduh tak sempat menyelesaikan penulisan kitab tafsir al-Manar dan dilanjutkan oleh Muhammad Rasyid Ridha.

Kitab yang terdiri dari lima jilid ini memiliki corak unik, karena ditulis oleh dua orang yang berbeda, maka tafsir ini memiliki dua sisi. Jika kita melihat penafsiran Najmuddin, maka terlihat di sana bahwa penulisnya selalu menyertakan makna zahir dan ketika ia akan mengungkapkan makna isyarinya ia menulis; "Isyarat dari ayat ini adalah demikian".

\section{e. Tafsir Allathif al-Isyaarah (Al-Qusyairi)}

Kitab ini disusun oleh seorang sufi bernama Qosim Abdul Karim bin Hawazin bin Abdul Malik Zain al-Islam Al-Qusyairi, yang lahir di Nasisapur daerah Kurasan Iran dan wafat tahun $465 \mathrm{H}$. Waktu hidupnya selalu dipakai untuk belajar, menghafal Qur'an, fiwig, theology asy-'ari, dan berguru pada guru besar Abu Ali Ad-Daqqaq (w.412/1021).

Imam Qusyairi adalah penulis produktif yang telah melahirkan sejumlah kitan diantaranya Risalah al-Qusyairi, al-Taisir fi al-Tafsir, Syakaabah ahl

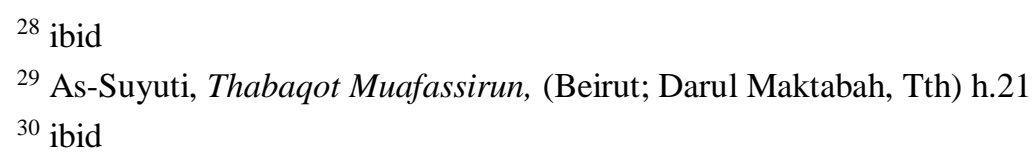


al-Sunnah dan lain-lain. Dalam kitab Lathaif al-Isyarah, ia mengungkapkan bahwa kitab ini berisi sisi isyarat al-Qur'an yang difahami oleh para ahli ma'rifat. Ia juga menegaskan bahwa ta'wil yang ia ungkapkan sama sekali tidak bertentangan dengan syari'at, karena ia berpendapat bahwa syariat yang tidak menguatkan sisi hakekat, maka syariat itu tidaklah maqbul. Tafsir ini adalah perjalanan terakhir setelah perjalanan tafsir. Penulis berusaha menyingkap rasa terdalam dari al-Qur'an yang didapatkan dari proses mujahadah.

\section{f. Tafsir al-Qur'an al-Karim (Muhyiddin Ibnu 'Arabi)}

Tafsir ini ditulis oleh seorang sufi besar Abu Bakar Muhyiddin Muhammad Ali bin Muhammad bin Ahmad Abdullahal-Hatimi al-Tha'i alAndalusi yang dikenal dengan Ibnu 'Arabi. Dia dilahirkan di Murcia Spanyol tahun 560 H/1165 M. konon kitab ini tidak langsung ditulis oleh Ibnu 'Arabi, melainkan oleh muridnya yang tulisannya dinisbatkan pada dirinya.

Sebagai sebuah kitab tafsir, tafsir Ibnu Arabi menempati posisi penting dalam hermeneutika irfani (Ta'wil). Walaupun pada awalnya tafsir tersebut kurang mendapatkan perhatian dan simpati dari masyarakat, tetapi kemudian memiliki tafsir ini menjadi suatu kualifikasi khusus dalam perkembangan penafsiran secara essoterik dalam sebuah penafsiran kontemporer. Selain memiliki ciri dan corak penafsiran tersendiri, tafsir ini juga menyuguhkan suatu penafsiran yang benar-benar beda dengan tafsir yang ada sebelumnya.

Kitab yang terbagi menjadi dua jilid besar ini muncul pada abad ke 7 dan ke 8. Tafsir ini berisi ta'wilan atas ayat-ayat al-Qur'an yang menggunkan metode isyari dan tasawuf nazhari. Seperti yang pernah ditulis oleh AzZahabi bahwa Ibnu Arabi dalam mena'wilkan setiap ayat al-Qur'an tidak terlebih dahulu mengemukakan makna zahirnya, melainkan mena'wilkan sepenggal sepenggal ayat al-Qur'an dngan langsung masuk ke dalam makna bathinnya.

Dalam menginterpretasikan teks-teks ayat, Ibnu Arabi jauh melangkah meninggalkan makna literal teks dan menyebrang kepada pemahaman simbolik. Karena salah satu formula hermeneutika adalah pertimbangan pada tiga aspek yaitu; 1) dalam konteks apa wahyu diturunkan, 2) bagaimana komposisi bahasa sebuah teks/wahyu diturunkan, 3) bagaimana spirit atau pandangan hidup yang terkandung dalam keseluruhan teks.

Karena pengaruh dari ajarannya Wihdatul Wujud, dia juga menempatkan al-Qur'an sebagai cermin yang mampu memantulkan seribu satu wujud sesuai dengan orang yang datang untuk bercermin dan berdialog dengannya. Jadi pemaknaannya yang jauh dari al-Qur'an sangah jauh dipengaruhi oleh alam pikiran, kultural, dan bahasa pihak yang membacanya.

Secara objektif, analisis terhadap tafsir al-Qur'an Karim karya Ibnu Arabi sebagai suatu hasil interpretasi dari wahyu, tidak terlepas dari penilaian terhadap validitas dan kualitasnya, sehingga analisa dapat diambil sebuah asumsi sementara yaitu ; Pertama, jika dilihat dari aspek sumber, maka dapat diklasifikasikan bahwa tafsir ini termasuk ke dalam tafsir isyari. Kedua, jika dilihat dari coraknya tafsir ini termasuk ke dalam corak tasfir sufi. Karena para sufi dalam memandang al-Qur'an tidak terbatas pada pengertian lahiriah 
saja, akan tetapi tersirat pada makna yang tersembunyi dibalik kata. Dengan kata lain, golongan sufi lebih menitikberatkan penafsirannya pada ta'wil. Ketiga, jika dilihat dari urutan tertib yang ditafsirkannya, maka tafsir Ibnu 'Arabi menggunakan metode tahlili, karena penafsirannya dengan mengikuti urutan tertib mushaf utsmani yakni mulai dari al-Fatihah sampai dengan AnNass.

Az-Zahabi melukiskan karakteristik pola penafsiran Ibnu Arabi yang sufistik dan perbedaannya dengan pola penafsiran ahli zahir, yang ia kutip dari statement Ibnu 'Arabi sendiri dalam kitabnya al-Futūhāt, dalam tulisan sebagai berikut:

"Segala ucapan yang keluar dari ahli hakekat berupa makna-makna isyarat dalam al-Qur'an, pada hakekatnya ia adalah tafsiran dan penjelasan terhadap maksud firman Allah. Ibnu 'Arabi meredaksikan dengan istilah isyarat, untuk membedakan dari ahli zahir. Selanjutnya bagaimana ia mengaku bahwa ahl Allah adalah orang yang paling berhak menjelaskan kitab Allah, sebab mereka menerima ilmu mereka langsung dari Allah, mereka membicarakan al-Qur'an atas dasar penglihatan mata hati, sedangkan ahli zahir berbicara tentang al-Qur'an berdasar dugaan dan perkiraan". 31

Berkata Syu'bah dari Abdullah bin Abi as-Safar bahwa As-Sya'bi berkata: "Demi Allah tidaklah suatu ayat turun kecuali aku bertanya tentang maknanya, tetapi akhirnya aku sadar bahwa penjelasan makna ayat itu adalah riwayat dari Allah".

Abu "Ubaid berkata, telah meriwayatkan hadis kepada saya Hasyim, telah meriwayatkan hadis kepada saya 'Amr bin Abu Zaidah dari As-Sya'bi dari Masruq ia berkata: "Hati-hatilah dengan tafsir sebab tafsir itu hanyalah riwayat dari Allah".

Kedua hadits di atas, memberi peluang kepada siapa saja untuk mendapat informasi langsung dari Allah menyangkut maksud ayat-ayat al-Qur'an. Dan hanya orang-orang yang terbuka hatinya yang dapat menangkap cahaya Tuhan tersebut yaitu para sufi. Meskipun pada awalnya kedua hadis di atas merupakan argumen tentang betapa penafsiran bi ar-ra'yi itu dilarang Rasulullah.

Dari pernyataan Ibnu 'Arabi di atas, nampak kelihatan bahwa pola kedua yang dijadikan landasan Ibnu 'Arabi dalam upaya menafsirkan al-Qur'an adalah al-faid atau pancaran dari Tuhan. Artinya pancaran ilmu yang langsung diberikan Tuhan ke dalam hati para sufi karena mereka telah berhasil mensucikan hati sesuci sucinya, sehingga cahaya Tuhan (berupa ilmu) datang dengan sendirinya sesuai dengan kehendak Tuhan. Dalam istilah sufi lain, al-Gazali, misalnya, ia menyebutnya dengan istilah ilmu ladunni (ilmu mukasyafah). Itulah sebabnya sebagian fakar tafsir menyebut pola penafsiran Ibnu 'Arabi sebagai pola penafsiran teosofi, seperti halnya tafsirtafsir sufi yang lainnya. ${ }^{32}$

\footnotetext{
${ }^{31} \mathrm{http}: / /$ faksyariah.blogspot.co.id/2013/11/tafsir-sufi-analisis-terhadap-metode.html ${ }^{32}$ ibid
} 


\section{Contoh Hermeneutika Irfani (Ta'wil)}

Ayat-ayat kisah dalam pandangan Ibnu Arabi bukanlah dongeng yang merujuk pada hal yang lebih essensial. Seperti Nabi Isa yang dia identikan dengan "symbol perwujudan", Nabi Sulaiman sebagai akal kreatif yang berada pada ketinggian jiwa di dalam dada. Nabi Ayyub disimbolkan dengan jiwa yang tenang (nafsul Muthmainnah) yang diuji dengan berbagai musibah sebagai riyadah (latihan) dan Nabi Zakaria yang disimbolkan dengan ruh dan kesederhanaan. ${ }^{33}$

Deskripsi tentang manusia terbaik ditemukan dalam al-Qur'an, ${ }^{34}$ “Kami menciptakan manusia dari tanah liat" dan "Aku telah menciptakanya dan meniupkan ruh-Ku ke dalam dirinya". Hal ini menggambarkan bahwa dalam diri manusia terdapat tiga aspek dasar unsur eksistensi manusia yaitu ruh, tubuh, dan jiwa. Dalam ayat ini ruh dinisbatkan pada Tuhan dan memiliki semua karakteristik realitas seperti bercahaya, halus dan satu. Ruh adalah tindakan kedermawanan suci dan wahyu, sedangkan tubuh memiliki sifat yang berlawanan gelap, kasar, dan beragam. ${ }^{35}$

Penciptaan Hawa dari tulang rusuk Adam menurut Ibnu Arabi adalah gambaran kualitas ibu (maternity) yang tersirat dalam wujudnya (Adam), sebab Hawa membuat Adam menjadi banyak. Ketika Hawa terwujud sebagai entitas yang terpisah dari Adam, maka Adam menjadi bagian dari pasangan, sehingga memunculkan rasa cinta diantara keduanya. Jadi Adam menjadi ayah setelah iap pernah menjadi pigur ibu. Demikian yang digambarkan oleh Sazhiko Murata. ${ }^{36}$

Hermeneutika irfani ( $t a$ 'wil) yang diterapkan Ibnu Arabi terhadap kisah Nabi Adam bisa kita lihat di bawah ini;

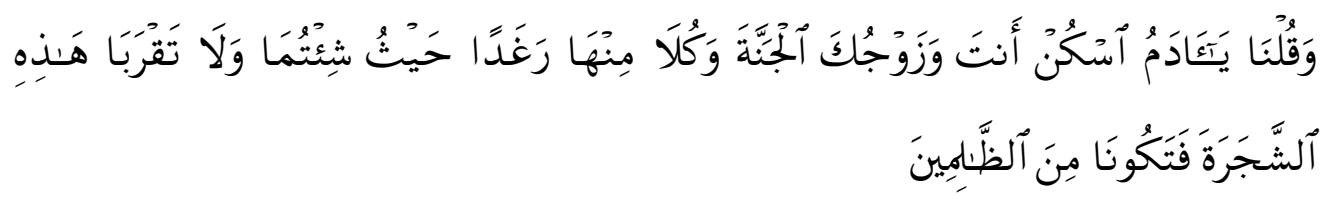

Ibnu Arabi tidak mengartikan ungkapan ayat tersebut dengan zahir, ia menangkap isyarat-isyarat bersifat simbolik. Kata jauzah (istri) sebagai an-Nafs (jiwa) yang bersemayam dalam jasad dan memiliki kecenderungan terjerumus dalam alam badani. Sedangkan kata al-Jannah (surge/kebun) merupakan symbol dari alam ruh dan taman kesucian (raudahal-Qudsiah). ${ }^{37}$

Ibnu Arabi sama sekali tidak menjelaskan bahwa Tuhan tidak sedang menceritakan kisah Adam dan buah Khuldi seperti pada umumnya tafsir. Bahkan perbincangan mengenai kesempurnaan ruh dan alam makrokosmik menurut $t a$ 'wil yang ia ungkapkan merupakan essensial dari ayat ini.

Coba kita bandingkan dengan tafsir al-Maraghi tentang jannah, dia menerangkan bahwa jannah adalah kebun di dunia antara Persia dan Kirman, h. $86-87$

${ }^{33}$ Ibnu 'Arabi, Tafsir al-Qur'an al-Karim, J.1 (Kairo: Daarl al-Yaqdhah, al'Arabiyah tth)

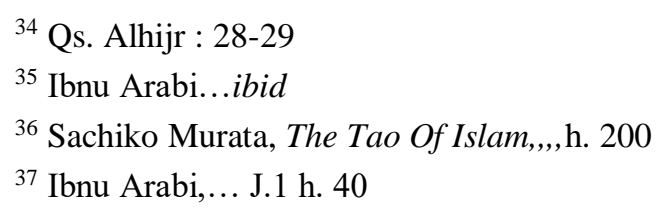


adapula yang mengatakan bahwa letaknya di Palestina. Sedangkan menurut Abu Hanifah dan pengikutnya Abu Mansur al-Maturidi, Jannah adalah kebun yang paling utama dari semua kebun tempat Adam dan istrinya hidup dan tidak usah memperbincangkan lebih mengenai posisi jannah tersebut. ${ }^{38}$ Kita lihat juga bagaimana tafsir Jalalain memberikan interpretasi terhadap kata jauz sebagai Hawa yang diciptakan dari tulang rusuk kiri Adam. ${ }^{39}$

Penafsiran di atas (hermeneutika eksoterik) bisa di lihat bahwa mereka hanya menangkap ayat-ayat itu dari lapisan yang paling bayani (zahiri/teks), tidak ada isyarat apapun yang diungkapkan selain makna asli dari ungkapan teks.

Kecenderungan/karakteristik penta'wilan ini bukan hanya ditemukan dalam karya Ibnu Arabi saja, melainkan dalam hampir semua pemaknaan al-Qur'an dengan hermeneutika eksoterik. Sebagai contoh penta'wilan kita bisa lihat beberapa penta'wilan yang dungkapkan oleh beberapa muawwil;

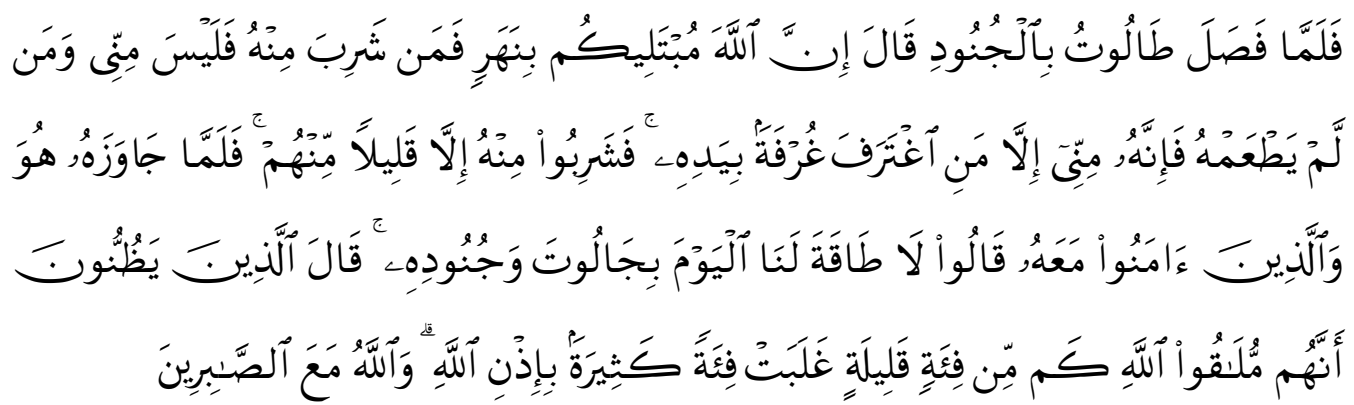

"Maka tatkala Thalut keluar membawa tentaranya, ia berkata: "Sesungguhnya Allah akan menguji kamu dengan suatu sungai. Maka siapa di antara kamu meminum airnya; bukanlah ia pengikutku. dan Barangsiapa tiada meminumnya, kecuali menceduk seceduk tangan, Maka Dia adalah pengikutku." kemudian mereka meminumnya kecuali beberapa orang di antara mereka. Maka tatkala Thalut dan orang-orang yang beriman bersama Dia telah menyeberangi sungai itu, orang-orang yang telah minum berkata: "Tak ada kesanggupan Kami pada hari ini untuk melawan Jalut dan tentaranya." orang-orang yang meyakini bahwa mereka akan menemui Allah, berkata: "Berapa banyak terjadi golongan yang sedikit dapat mengalahkan golongan yang banyak dengan izin Allah. dan Allah beserta orang-orang yang sabar."

Najmudin Dayah dalam al-Ta'wilat an-Najmiyah mengungkapkan bahwa kata "sungai" disana bukanlah sungai secara zahir, ia adalah lambing dari sungai dunia (an-Nahr Dunia). ${ }^{40}$ Najmuddin kemungkinan melihatnya bahwa kisah thalut ia tidak sedang menceritakan sebuah kisah masa lalu, melainkan sedang menggambarkan kehidupan manusia dalam hubungan dengan godaan dunia.

Contoh lain adalah ta'wilan al-Syairazi ketika menafsirkan surat an-Nahl yat 81 ;

\footnotetext{
${ }^{38}$ Ahmad Mustofa al-Maraghi, Tafsir al-Maraghi (Beirut : Darul Ihya, tth) J.1 h. 90

${ }^{39}$ Jalaludin As-Suyuti, Jalaludin al-Mahalli, Tafsir al-Qur'an al-Adzim,

${ }^{40}$ Az-Zahabi, Tafsir wal Mufassirun, j.2 h.396
} 


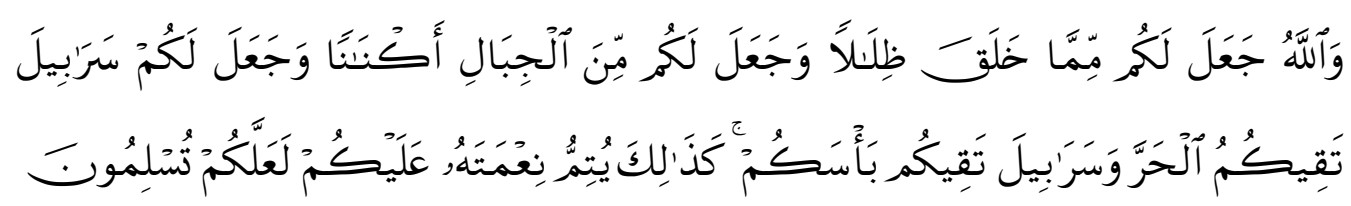

"dan Allah menjadikan bagimu tempat bernaung dari apa yang telah Dia ciptakan, dan Dia jadikan bagimu tempat-tempat tinggal di gunung-gunung, dan Dia jadikan bagimu pakaian yang memeliharamu dari panas dan pakaian (baju besi) yang memelihara kamu dalam peperangan. Demikianlah Allah menyempurnakan nikmat-Nya atasmu agar kamu berserah diri (kepada-Nya)".

Contoh lain dari ta'wil adalah surat an-nahl ayat 81, dalam ayat itu disebutkan dzilal yang berarti payung atau bayangan. Ia mena'wilkan bahwa yang dimaksud disana bukan memayungi secara fisik, melainkan secara simbolik yaitu gambaran seorang guru atau pembimbing spiritual yang menjadi payung bagi murid-muridnya. ${ }^{41}$

Contoh lain untuk memperkuat pemikiran ini bisa kita lihat penta'wilannya terhadap ayat yang mutasyabihat, diantaranya ayat-ayat muqottoah. Pada dasarnya terdapa dua kubu ulama yang mengomentari persoalan di atas yaitu; Pertama kubu salaf yang memahami sebagai rahasia yang dimana Allah yang mengetahuinya. Kedua kubu yang melihat persoalan itu sebagai suatu rahasia yang dapat diketahui manusia. ${ }^{42}$

Sebagai contoh penafsiran Ibnu Arabi terhadap Qs Al-Baqoroh, dia menulis;

"Huruf-huruf ini merupakan isyarat bagi tiga unsur al-wujud. Alif merupakan isyarat bagi dzat al-Wujud sedangkan Lam mengisyaratkan akal yang aktif yang dia sebut Jibril, dan dia merupakan wujud pertengahan yang meminta cahaya dari dzat terakhir. Sedangkan Mim mengisyaratkan Muhammad yang merupakan akhir dari al-wujud dan menyempurnakan wilayahnya dan bersambung dengan wujud awal. ${ }^{43}$

Dalam menjelaskan makna huruf muqottho'ah ini Ibnu Arabi tidak selalu mengemukakan pendapat pribadinya terkadang juga mengutif suatu hadits, seperti awal surat al-A'raf (المص.... ) dia mengutip hadits dari Ibnu Abbas ;

$$
\text { " ص " جبل في مكة عليه عرش الرحمن حين لا ليلا ولا هنار }
$$

"huruf shad adalah gunung di Mekkah yang merupakan arasy al-Rahman (Allah) pada suatu waktu yang bukan malam dan bukan pula siang”.

Ibnu Arabi memberikan penjelasan bahwa yang dimaksud dengan gunung disini adalah jasad Muhammad berdasarkan sebuah hadits;

$$
\text { قلب المؤمن عرش الله }
$$

"Hati seorang mu'min adalah arasy Allah".

Namun dia tidak mencantumkan riwayatnya atau mukharrijnya.

\footnotetext{
${ }^{41}$ Ibid,h. 392

${ }^{42}$ Rosikhon Anwar, Samudra al-Qur'an, (Bandung: Pustaka Setia, 2001) cet. Ke 1,h. 99

${ }^{43}$ Ibnu Arabi,,, h.13
} 
ISTIGHNA, Vol. 2, No 2, Juli 2019 P-ISSN 1979-2824

Homepage: http://e-journal.stit-islamic-village.ac.id/index.php/istighna

Supriadi

Keberpihakan Pada Bayani Atau Irfani

(Sebuah Pendekatan Baru dalam Memaknai Teks Al-Qur'an)

\section{KESIMPULAN}

Sesuai dengan karakternya yang bersifat isyari, hermeneutika irfani (ta 'wil) selalu melihat semua fenomena (termasuk teks) sebagai sesuatu yang memiliki makna. Salah satu yang berlaku dalam ta'wil adalah menganggap bahwa alQur'an sebagai sebuah teks memiliki kesetaraan secara parallel dengan berbagai fenomena al-Wujud.

Dengan keyakinan dan didukung oleh berbagai dalil bahwa al-Qur'an memiliki lapisan makna luar (zahir) dan dalam (bathin) pasti memiliki hirarki makna. Bahkan penelaahannya sampai melampaui batas makna teks. Proses inilah yang membuktikan bahwa Ibnu Arabi sebagai sufi telah melakukan proses hermeneutika Irfani yang meniscayakan imajinasi, dan intuisi.

\section{REFERENSI}

Abdurrahman Habil, Tradisionalisme Essoteric Commentaries on the Qur'an dalam Sayyid Husein Nashr (ed). New York: Crosroad, 1987

Bambang Sugiharto, Post Modernisme; Tantangan bagi FIlsafat, Yogyakarta, Kanisius, 1996

E Sumaryono, Hermeneutika; Sebuah Metode Filsafat, Yogyakarta; Kanisius, 1999

Gini Graham, Mind Power, Jakarta: Grasindo,

Henry Corbin, Creative Imagination in the Sufism of Ibnu Arabi, Princenton University Press,

Ibnu Arabi, Tafsir al-Qur'an al-Karim,

M. Husein Az-Zahabi, Tafsir wal Mufassirun, Mesir: Darul Kitab al-Arabi,

Jon, L Esposito, The Oxpord Ensiklopedia of The Modern Islamic World, (terj) Bandung: Mizan, 2001

Jalaludin As-Suyuti, Al-Itqon Fi Ulumil Qur'an, Beirut : Manshurat hadits

Muhammad Az-Zarqoni, Manahill Irfan, Beirut : Al-Bab al-Haly

M. Quraish Shihab, Membumikan al-Qur'an, Bandung: Mizan

MS. Kaelan, Filsafat Bahasa, Masalah dan Perkembangannya, Yogyakarta: Paradigma,

Osman Bakar, Tauhid dan Sains; Essai-Essai tentang Sejarah Filsafat sains Islam, Bandung: Pustaka Hidayah

Sachiko Murata, The Tao Of Islam, (Terj) Bandung: Mizan

Willian C. Chittik, Imaginal World; Ibnu Arabi and the Problem of Religion Diversity, New York: State University of New York. 